\title{
A Kuri Beef (Bos Taurus) Imported From The Lake Chad Has Introduced Hyalomma Impeltatum (Acari: Ixodidae), An Anthropophilic Tick To Gabon
}

\author{
D. Moubamba Mbina, G. D. Maganga, and A. Ndoutoume Ndong
}

\begin{abstract}
The cross-border trade cattle, involve the movement of several thousands of animals with the risk of introduction of zoonotic diseases and vector borne-diseases between the countries. It was during a trade transaction that a kuri beef (Bos Taurus) coming from the lake chad area in order to cover the needs in meat of the populations of Gabon has introduced Hyalomma impeltatum an anthropophilic tick. The risk of introduction in Gabon of pathogens such as the arbovirus Sindbis and Dhori; the virus of Crimea-Congo hemorrhagic fever, Rickettsia africae as well as Rickettsia aeschilmannii is a real threat for public health. The treatment of cattle with effective acaricides at the frontier before entering to Gabon can prevent the introduction of ticks and tick borne diseases.
\end{abstract}

Index Terms - Cattle; Public; Health; Kuri; Lake; Gabon.

\section{INTRODUCTION}

Cross- border trade cattle involve the movement of animals among countries or regions. In West Africa, this movement is oriented from Sahel countries such as Mali, Burkina Faso, Niger to Coastal countries which are Cote d'Ivoire, Ghana, Nigeria. In 2000, the cattle population in this part of Sahel was estimated at 47 million of animals and the financial transactions from these countries in the south west of Africa towards Mali, Burkina Faso and Niger was \$ 150 million for the same period [1]. Regarding Eastern countries, Ethiopia is the main contributor because from 1998-2014 the cross-border trade cattle of this country has reached 60 billion of which 16 billion live livestock was sold to Kenya, Somalia and Djibouti. A part of small ruminants from this trade was shipped to Gulf countries via Somalia [2]. In Central Africa with 127 cattle markets, Cameroon is the cross-road for cross-border cattle trade for ruminants coming from Chad, Centre Africa, and Nigeria sold in Gabon and Equatorial Guinea. Between September 2013 and August 2014, 235,831 cattle have moved through these markets [3]. The movements of several thousands of animals in the cross-border cattle trade among countries or regions are a real risk for spreading zoonotic diseases [3] and vectors of diseases such as ticks [29]. For the first time in Gabon a Kuri beef imported from lake Chad has introduced an anthropophilic tick. The objective of this

Published on October 3, 2019.

Moubamba Mbina D, Laboratoire de Zootechnie, Institut de Recherches Agronomiques et Forestières, B.P.2246, Libreville, Gabon (E: ddm040@yahoo.fr)

Maganga D. G, Centre International de Recherche Médicales de Franceville, B.P. 769, Franceville, Gabon (Email Gael maganag@yahoo.fr)

Ndoutoume Ndong A, Laboratoire d'entomologie et des protections des cultures, Institut de Recherches Agronomiques et Forestières, B.P.2246, Libreville, Gabon (Email : augustndoutoume@yahoo.fr) study was to characterize this animal and the specie of tick he has introduced in this country and also to present the potential diseases this arthropod could transmit to the populations. In order to protect public health, a preventive acaricide treatment was recommended to cattle imported from Cameroon to Gabon before crossing the frontier.

\section{MATERIAL AND METHODS}

\section{A. Slaughterhouse of Libreville}

The survey was conducted during the month of June 2019 in the municipality of Owendo at a slaughterhouse in the south of Libreville; the first town of Gabon.

\section{B. Animal}

A six years old beef imported from lake Chad to Gabon was examined during an ante-mortem examination in the slaughterhouse of Libreville to collect ticks and also to characterize this animal. Factsheets were used for the characterization [4], [5]. In order to identify the site where the imported tick was collected, the body of this animal was divided in 6 parts (head, neck, abdomen, legs, perineum and back.

\section{Tick}

The tick was collected manually and kept in a tube containing $3 \mathrm{ml}$ of ethanol at $70 \%$. In order to identify the specie to which this arthropod belonged, identification keys [10], [26] and a binocular loupe were used.

\section{RESUlts}

\section{A. Beef Characterization}

The animal (Figure 1) that has introduced an anthropophilic tick in Gabon was a Kuri beef (Bos Taurus) belonging to the group of humpeless cattle breeds with longhorns of sub-Saharan Africa [4], [5].

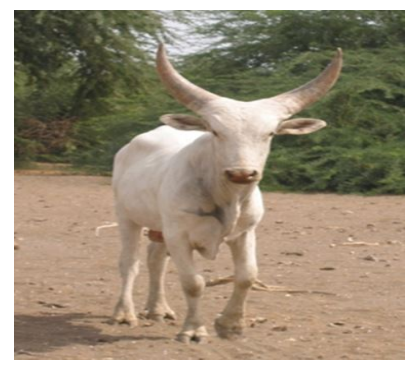

Fig.1. Kuri cattle (Bos Taurus) 


\section{B. Tick Identification}

The tick (Figure 2.A-B) collected from the Kuri beef belonged to the phylum of Arthropoda, the class of Arachnida, the order of Acarina, the Sub-order of Ixodoidae, the family of Ixodidae, the genus of Hyalomma and the specie Impeltatum [10], [26].

(a)

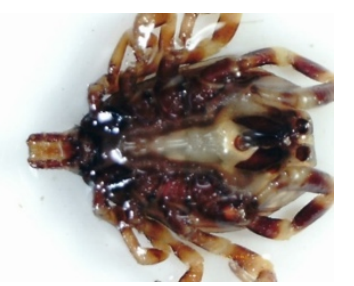

impeltatum dorsal view

\section{DiscUSSION}

This survey has showed that, a kuri beef has introduced an anthropophilic tick Hyalomma impeltatum in Gabon. This animal belonged to the type of African Bos Taurus cattle, more exactly to the group of humpeless long horn cattle [5]

Kuri cattle are larger than both West Africa taurins and zebu cattle [4] with mature weight range from $360-750 \mathrm{~kg}$ [8], These animals have voluminous and bulbous horns with a basal section reaching between $20-100 \mathrm{~cm}$ in circumference [8] but these measures were shorter than to those of Ankole-watusi which reach $103.5 \mathrm{~cm}$ [7]. The meat yield of these cattle is 50 percent for the beefs of seven years old [27]. With a production of 6-10 liters per day, this breed is a better milk producer than arab zebu representing 90 percent; of the population of cattle in Chad with only 1.54 liters per day [27]. Kuri cattle are well adapted to the semiacquatic environment. These animals live on shores and Islands of lake Chad and are also distributed among Northern Nigeria southern Chad, Nguigni province in Niger and northern of Cameroon. This area was located in Sahel which had a semi-arid climate with annual precipitations between $200 \mathrm{~mm}-600 \mathrm{~mm}$, a range of temperatures $24^{\circ} \mathrm{C}$ $34^{\circ} \mathrm{C}$ and a relative humidity between $65 \%$ to $84 \%$ [9]; these climatic conditions were suitable to Hyalomma impeltatum [10]. With a population estimated at 110,000 heads [6], kuri cattle are threatened of instinction today because of, drought, the reduction of his habitat, the rinderpest, the difficulties political situation of the countries bordering around this area as well as the retreating of waters of lake [8]. In order to cover the needs of meat for the populations, Gabon has imported cattle from Cameroon [3] for several years, but concerning cattle coming from lake Chad, it was the first time that a Kuri beef was introduced in This country.

Hyalomma impeltatum was introduced in Gabon attached to the testicles of a Kuri beef coming from lake Chad. Under laboratory conditions, this arthropod has; a three- host life cycle [10]. Arid and semi-arid climates are suitable for this acarian, which is distributed from North African to Midldle- Eastern countries, via the Sahel [10]. Usually, adults of this acarian infest Cattle and camels [11]. Hyalomma impeltatum carrie1s Rickettsia africae a human infectious pathogen [12] but no transmission associated with this tick has ever been reported to date, in Africa, only both Amblyomma variegatum and Amblyomma hebraeum are recognized as being the main vectors associated with this bacteria [12]. The symptoms [13] of the infection due to $R$. africae are: Fever, rash, chills, asthenia, anorexia and myalgia Doxycline therapy remains the best choice of treatment [12]. Other zoonotic pathogens such as: Rickettsia aeschilmanii [15], Ehrlichia chaffensis [14] as well as both Sindbis and Dhori viruses belonging to the Togaviridae and Orthomyxoviridae families respectively were detected; but no case of infected human has ever been reported to date, therefore Hyalomma impeltatum can be considered as an epidemiological indicator for both rickettsia and viruses cited above. On the other hands it has been showed that Hyalomma_marginatum [15] and Amblyomma americanum [14] were able to transmit the pathogens Rickettsia aeschilimanii and Ehrlichia chaffensis respectively to human beings; the same goes for Sindbis and Dhori viruses for which mosquitoes belonging to the genera Aedes [16], [17], and Culex [16], [17] were the main vectors but only those of the genera Culiseta sp [17] and Anopheles sp [16] are able to inoculate these two pathogens to men. Symptoms due to Rickettsia aeschlimannii [18] are similar to those of $R$. africae but Ehrlichia chaffensis induces in addition arthralgias, vomiting, cough, abdominal pain, diarrhea, conjunctivitis, peripheral edema as well as pharyngitis [14], doxycline is also recommended, in the treatment of infections associated with E. chaffensis [14]. Regarding both Sindbis and Dhori arboviruses, the symptoms are similar to those cited above linked to Rickettsia sp and Ehrlichia sp; with other symptoms such as: Giddiness, eyeball pain, scleritis, bradycardia and nervous troubles; specific to the Dhori virus [19]. Because the clinical features of the tick-borne diseases quoted above are similar to those of malaria, influenza and viral infection associated to dengue this can lead to misdiagnosis. Therefore, performing, laboratory diagnostic remains the best way to establish a differential diagnostic. Symptomatic treatments are administrated to patients suffering about the infections associated to both Dhori and Sindbis virus but non-asteroid anti-inflammatories are recommended for the troubles due to Sindbis virus [25]. With an average of rainfall between $60-700 \mathrm{~mm}$, arid and semi-arid areas are comfortable biotopes for Hyalomma impeltum but equatorial regions with hydrophilic forests [20] and an average of precipitations between $1400 \mathrm{~mm}-3500 \mathrm{~mm}$ like Gabon [22] constitute uncomfortable environment for this arthropod therefore Hyalomma impeltatum cannot survive in Gabon because of excess of water but wildlife and domestic animals can play the role of reservoirs from which other arthropods hematophagous could be contaminated before transmitting the zoonotic pathogens to men; that fact could threat public health [28]. Like many other ticks of the Hyalomma genus Hyalomma impeltatum transmits to humans the Congo and Crimea hemorrhagic fever virus with a range of symptoms such as: fever, myalgia, dizziness, neck pain and stiffness, headache, sore eyes, nausea, vomiting, diarrhoea, abdominal pain, sore throat and other clinical signs including tachycardia, petechial rashes, ecchymoses, and other hemorrhagic phenomena [21]. The case fatality rate reported during the outbreaks can move up to $40 \%$ [21]. General supportive care with symptomatic treatments are the main approach to managing $\mathrm{CCHF}$ in 
people. The antiviral drug ribavirin has been used to treat $\mathrm{CCHF}$ infection with apparent benefit. Both oral and intravenous formulations seem to be effective [21]. Because Gabon is not a favorable habitat for Hyalomma impeltatum, the risk of transmission of the virus of CCHF to people is low but cattle, sheep, goats, birds, and hares hosts of this acarian considered as potentials reservoirs of this arbovirus, remain a threat for public health [23] The use of Topline (Fripolin) pour on at $1 \%$ as acaricide treatment performed to cattle crossing the border between Cameroon and Gabon [24] can prevent the introduction of ticks and tick-borne diseases which can threat public health.

\section{CONCLUSION}

This survey has showed that the cross-border trade cattle facilitate the movement of ticks and zoonotic borne diseases between countries, veterinary controls and acaricide treatments remain the best way to protect public health when cattle cross frontiers.

\section{ACKNOWLEDGMENT}

The authors thank the head of AGASA (Agance Gabonaise pour la Sécurité Alimentaire) and Dr. Gilles Boupana, for their efforts that has helped them conducting the investigations at the abattoir of Libreville.

\section{REFERENCES}

[1] T.O. Williams, B. Spycher and I. Okike, improving livestock marketing and intra-regional trade in West Africa: Determining appropriate economic incentives and policy framework. ILRI (International Livestock Research Institute), Nairobi, Kenya: 2006 pp. $10-11$.

[2] A. Tesfaye and N. Amaha," A Review on Cross-Border Livestock Trade Across Dry Land Borders of Ethiopia: The Trends and Implications," J. Sci. Inno. Res.,.Vol. 7, no.2, pp. 36-42, September2018.

[3] P. Motta, T. Porphyre, I. Hande, S. M. Hamman, V. Ngu Ngwa, V. Tanya, K. Morgan, R. Christly and B. M. de C. Bronsvoort," Implications of the cattle trade network in Cameroon for regional disease prevention and control", Scientific Reports," Vol.7, no. 43932, pp. 1-12. March 2017/

[4] M. Grema, A. Traoré, M. Issa, M. Hamani, M. Abdou, I. Fernández, A. Soudré, I. Álvarez, M. Sanou, H.H. Tamboura, Y. Alhassane and F. Goyachev.," Morphological assessment of Niger Kuri cattle using multivariate methods," S. Afr. J. Anim. Sci., vol. 47, no.4, pp. 509515 .

[5] J.E.O. Rege, "The state of African cattle genetic resources I. Classification framework and identification of threatened and extinct breeds," Animal Genetic Resources Information, Vol. ILRI-25, pp. 125, 1999.

[6] J.E.O. Rege and C.L. Tawah, "The state of African cattle genetic resources II. Geographical distribution, characteristics and uses of present-day breeds and strains," Animal Genetic Resources Information, Vol.ILRI- 26, pp.1-131, 1999.

[7] Guinness World Records. Largest horn circumference - bull London., UK, 2004. https://www.guinnessworldrecords.com/worldrecords/largest-horn

[8] N. Mpofu and J.E.O. Rege, “ The unique Kuri cattle of the Lake Chad Basin., " Addis Ababa, Ethiopia: 2002, . pp. 1-9. https://cgspace.cgiar.org/.../casestudy-Mpofu-Kuri1.pdf?...1...y (2002).

[9] M. Tellah, V. Zeuh, L.Y. Mopaté, F. M. Mbaïndingatoloum and H. Boly," Paramètres de reproduction des vaches Kouri au Lac Tchad, “ J. Appl. Biosci., Vol. 90, pp. 8387-8396. June 2015.

[10] A.R. Walker, A. Bouattour, J. L Camicas, A. Estrada-Penas, I.G. Horak, A.A. Latif, R. G. Pegram. and P.M. Preston, Ticks of Domestic Animals in Africa: A guide to identification of species of ticks, 1st ed. University of Edinburgh, UK: Bioscience reports, PP. 1219. 2003

[11] M.S. El-kalifa, F/M.Diab, G.M. Khalil," Man-threating viruses isolated from ticks in Saudia Arabia.," Saudi.Med. J. vol. vol. 28, no. 12, pp. 1864-1867. June 2007.
[12] J Frean, L Blumberg, G.A. Ogunbanjo, "Tick bite fever in South Africa,”. SA. Fam. Pract. Vol.50, no.2,:pp. 33-35. 2008

[13] N. Roch, O. Epaulard, I. Pelloux, P. Pavese, J.P. Brion, D. Raoult and M. Maurin," African Tick Bite Fever in Elderly Patients: 8 Cases in French Tourists Returning from South Africa," Clin. Infect. Dis., Vol. 47, no.3, pp. 28-35. August 2008.

[14] C.D. Paddock and J.E. Childs," Ehrlichia chaffeensis: A Prototypical Emerging Pathogen,". Clin. Microbiol. Rev., Vol. 16, no. 1, pp. 3764. Jan. 2003

[15] A. Germanakis, D. Chochlakis, E. Angelakis, Y. Tselentis and A. Psaroulaki," Rickettsia aeschlimannii Infection in a Man, Greece," Emerging Infectious Diseases. Vol,19, no.7, pp.1175-1177. July 2013

[16] P.A Nuttall and M Labuda.nn " Dynamics of infection in tick vectors and at the tick-host interface," Adv. Virus. Res.; Vol.60, pp.:23372..2003. https://www.sciencedirect.com/topics/medicine-anddentistry/thogoto-virus

[17] Goverment of Canada. Pathogen Safety Data Sheets: Infectious Substances - Sindbis virus (SINV). Public Health Agency, Canada, 2011. https://www.canada.ca/en/public-health/services/laboratorybiosafety-biosecurity/pathogen-safety-data-sheets-riskassessment/sindbis-virus-pathogen-safety-data-sheet.html

[18] L. Beati, M. Meskini, B.Thiers and D. Raoult, " Rickettsia aeschlimannii sp. nov., a new spotted fever group rickettsia associated with Hyalomma marginatum ticks," Int. J. Syst. Bacteriol.. Vol. 47, pp.548-554.1997 http:// dx.doi.org/10.1099/00207713-47-2-548.

[19] S. Ya. Gaidamovich1, A. M. Butenko1, and H. V. Leschinskava.," Human laboratory acquired Arbo, Arena - and hantavirus infections, “ Journal of the American Biological Safety Association, vol. 5, no.1, pp. 5-11. 2000.

[20] Aeschlimann, " Biologie et écologie tiques Côte d'Ivoire : genre Hyalomma.' Acta. Tropica. Vol. 24, no. 4, pp. 345-351. 1967. http://www.e-periodica.ch

[21] WHO, Crimean-Congo hemorrhagic fever, Geneva Switzerland, 2013. https://www.who.int/news-room/factsheets/detail/crimeancongo-haemorrhagic-fever

[22] Ministère de I 'Education Nationale de la République Gabonaise, Institut Pédagogique Nationa, Géographie et cartographie du Gabon atlas illustré : Climatologie, OROSTOM fond documentaire no. 21243, PARIS, France. https://www.google.fr/search?q=climat $+\% \mathrm{C} 3 \%$ A 9 quatorial + pdf\&sa $=$ X\&ved=2ahUKEwi09vO11NXjAhUE9BoKHSmPAu84FBDVAigBe gQIChAC\&biw $=1366 \&$ bih $=646$

[23] Centers for Disease Control and Prevention, Crimea-Congo hemorrhagic fever ecology virus, Atlanta, GA, 2013. https://www.cdc.gov/vhf/crimean-congo/resources/virus-ecology.html

[24] M.L Dia, Y. Barry and A. Old M'Rezig. Trial on the Efficiency of Topline ${ }^{\circledR}$ Against Natural Tick Infestations of Dromedaries in Mauritania. Journal of Veterinary Science \& Animal Husbandry, Vol. 6, no. 2, pp.1-6, May 2017

[25] J. Sane." Sindbis virus as a human pathogen: Epidemiology, virology, genetic susceptibility and pathogenesis", Academic Dissertation, Dept. of virology, University of Helsinki, Helsinki, Finland, 2012.

[26] J. Okelo-Onen, S.M. Hassan and S. Essuman, Taxonomy of African Ticks: An identification manual, Nairobi, Kenya: ICIPE, 1999, PP. 1124.

[27] I. Zborowski, Livestock atlas of the Lake Chad Basin, Wageningen, Netherland: $\quad$ CTA. pp $88-90 . \quad$ w.w.w. agritrop.cirad.fr/388415/1/L\%27élevage\%20du\%20boeuf\%20Kouri.p df

[28] P.Y. Bitome-Essono, B. Ollomo, C. Arnathau, P. Durand, N. Diamella Mokoudoum, L. Yacka-Mouele, A.P. Okouga, L. Boundenga, B. Mve-Ondo, J. 1. Obame-Nkoghe, P. MbehangNguema, F. Njiokou, B. Makanga, R. Wittier, D. Ayala, F. J. Ayala, F. Renaud, V. Rougeron, F. Bretagnolle, F. Prugnolle and Ch. Paupy, "Tracking zoonotic pathogens using bloodsucking flies as 'flying syringes, "Ecology Epidemiology and Global Health, Vol. 6, no. 22069, pp. 1-21.

[29] J. D. Busch, N.E. Stone, R. Nottingham, A. Araya-Anchetta, J. Lewis, Ch. Hochhalter, J. R. Giles, J. Gruendike, J. Freeman, G. Buckmeie, D. Bodine, R. Duhaime, R. J. Miller, R. B Davey, P. U. Olafson, G. A. Scoles and D. M. Wagner," Widespread movement of invasive cattle fever ticks (Rhipicephalus microplus) in southern Texas leads to shared local infestations on cattle and deer," Parasites \& Vectors, Vol. 7, no. $188, \quad$ pp.1-16, 2014. http://www.parasitesandvectors.com/content/7/1/188 


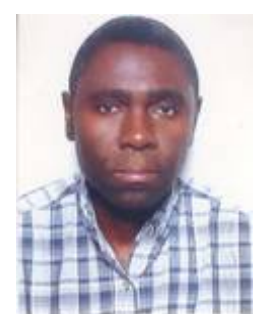

Moubamba Mbina Dieudonné (Lead author) Place of birth day: Libreville, Estuaire, Gabon. Date of birth day: 15 July 1964. Educational background: Master of animal health (MSc. Vet.), Institute of Tropical Medicine of Antwerp (ITM), Antwerp, Belgium, November 1997. PhD in progress in public health, Texila American University and Central University of Nicaragua.

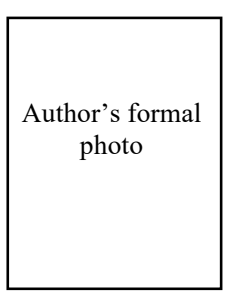

Maganga Gael Darren. Place of birth day: Libreville, Estuaire, Gabon. Date of birth day: 19 May 1980. Educational background: DVM, university Cheick Anata Diop, Dakar, Senegal, 2005. PhD in

Author's formal photo molecular virology, Montpellier 2 University (France), 2015

Ndoutoume Ndong Auguste. Educational background: $\mathrm{PhD}$ in Entomology, University of François Rabelais of Tours, Tours, France, 1996. 